\title{
Review of studies focused on bilingualism
}

\begin{abstract}
Hülya Sönmez ${ }^{\text {a }}$
APA Citation:

Muş Alparslan University, Education Faculty, Muş, 49100, Turkey

Sönmez, H. (2019). Review of studies focused on bilingualism. Journal of Language and Linguistic Studies, 15(3), $1045-1068$.

Submission Date: 07/03/2019

Acceptance Date:13/08/2019

Abstract

The purpose of this study is to determine the purpose, scope, research model, data collection tool, data analysis method and sample size of the studies on bilingualism. According to the general screening model, the documents collected were analyzed. In the first step, in order to determine the focus and scope, the objectives of the sample studies were examined based on the descriptive analysis. In the second step; research model, data collection tools, data analysis methods, and the number of participants of the studies were examined. Thus, the scope of the studies was determined. For this purpose; research models, data collection tools, data analysis methods and the number of participants were examined. Based on the conclusions of this part, it was determined that the experimental and descriptive models were frequently used in sample the studies.
\end{abstract}

(c) 2019 JLLS and the Authors - Published by JLLS.

Keywords: Bilingualism; purpose; scope; education

\section{Introduction}

\subsection{Literature review / Theoretical background}

From the $19^{\text {th }}$ century to the 1960 s, believed that bilingualism had a detrimental effect on cognition (Laurie, 1890; Darcy, 1953; Náñez et al., 1992, Narrated by Baker, 2001, p.136). However, after the 1960s, it has been determined that some aspects of bilingualism (mental flexibility, balanced bilingual, cognitive advantages) have positive effects on cognition such as intelligence (Peal and Lambert, 1962, Narrated by Baker, 2001, p.136). Nowadays, other factors that are effective in the spread of bilingualism are education and professional development. Because it is an important factor to communicate with people who are different countries in a common language. Therefore bilingualism is being an important phenomenon.

Bilingualism, which is more important depending on the communication needs, is a phenomenon considered as a necessity in many aspects. Because of economic, social, political, geographical, etc. factors, people have to live in a new country. The main requirement of these migrants is to learn the language of the country in which they live. And governments focus on bilingual education to ensure immigrants' integration in the country. In response to these needs, bilingual education is an important educational policy. To evaluate the bilingual education curriculum in Europe functionality of bilingual

\footnotetext{
a Corresponding author. Tel.: +0-5066118629

E-mail address: hulya..sonmez@alparslan.edu.tr or hulyasonmez49@gmail.com
} 
education is examined. According to the findings, it was determined that there is a need for bilingual schools, which also include instruction in the mother tongue of minority children. At the same time, further studies on bilingual education in Europe are needed (Reljić, Ferring and Martin, 2016). In another meta-analysis study conducted curriculum-oriented, was done on bilingual education in Arizona. Bilingualism has positive effects on all criteria in English according to the results of experimental studies conducted on bilingual education. In addition, bilingualism is also influential on students' academic achievement in their mother tongue. It was determined that bilingualism developed students' academic skills in both languages (Rolstad, Mahoney, and Glass, 2005, p. 61).

Another domain in which meta-analysis studies focused on is functional neuroimaging studies of bilingualism. The aim of the studies was to quantify the results of a series of neuroimaging studies on bilingualism. Despite several experimental tasks in the meta-analysis study, it was seen that bilingualism has effective in the creation of a similar neural representation of the regions that play a role on the nerve basis on two languages. At the same time, there are several differences in the use of first and second languages in low-level bilingual individuals (Sebastian, Laird, and Kiran, 2011). The effects of earlyexposed and later-exposed factors on bilinguals were found to be different in the study. The results showed that early exposure to bilingualism does not alter the brain regions that manage high cognitive executive functions. Instead, it provides basic changes in classical language skills. At the same time, the prefrontal cortex is more effective on later-exposed bilinguals (Jasinska and Petitto, 2013).

Another domain of the studies that focus on meta-analysis research is the relation between bilingualism and cognitive. In these studies, the effects of bilingualism on cognitive were evaluated with different aspects. The analyzes in this context indicate that bilingualism is associated with cognitive outcomes such as increased attentional control, working memory, metalinguistic awareness, and abstract and symbolic representation skills (Adesope, Lavin, Thompson and Ungerleider, 2010, p. 219). However, in some studies, it was emphasized that bilingualism had no positive or negative effect on intelligence development such as metalinguistic awareness and cognitive development (Barac and Bialystok, 2016, p. 36). On the other hand, in some studies, it has been observed that bilingualism has a retarding effect on the process of acquiring some formal aspects such as vocabulary (Bialystok, 2010, Narrated by Barac and Bialystok, 2016, p. 36). Because bilingualism is thought to cause problems such as burden on the brain, mental confusion, inhibition of the acquisition of the majority language, identity conflicts, split loyalties, even schizophrenia on cognitive. Therefore, warnings such as "Don't raise your child bilingually or problems will result" are given for this situation (Baker, 2001). In another comprehensive meta-analysis study, the effect of bilinguals and monolinguals factor on working memory capacity of cognitive processes such as cognitive flexibility, conflict monitoring, and taskswitching abilities was investigated. In the study, it has been determined that the bilingual factor has more executive function advantages on working memory capacity than monolingual factor (Grundy and Timmer, 2017, p. 133-p. 136). Therefore, the effect of bilingualism on language development and speech has been examined from various aspects. The results show that there is no significant difference between the development of a bilingual child's language and the development of a monolingual child's language in a particular language (De Houwer, 2005).

Germany needs bilingual education and bilingual programs. Because although there are some bilingual classes in secondary school there are no more than two dozens of these experimental projects which have immigrant-minority languages as the partner language. Only a minority of bilingual schools or classes deal with the problem of immigrant minorities. Because of these issues, it is seen that experimental studies (strategy development, curriculum design, material preparation, etc.) related to bilingual education are needed in Europe (Gogoli, 2005, p.137-p.138). The curriculum and the measurement and evaluation process had been prepared for students who are monolingual. Unfortunately, this problem continues in many countries for so many years and unfortunately this factor 
affects them in many ways, primarily the cognitive development of bilingual learners (Akınc1, 2006). Due to these problems, only a very small number of bilingual students are able to complete their education after an intensive study period (Vallet and Caille, 2000). And some students lost most of their skills on the mother tongue over time as they are very focused on the second language. As a matter of fact, this is one of the main risks that bilinguals will experience (Schmit, Köpke, Keijzer, and Weilemar, 2012). At the same time, immersion programs in which children are taught only in the school language appear to be associated with low-level second language proficiency, scholastic insufficiency, and psychosocial disorders (Hakuta and Mostafapour, 1996). Because the content of the programs includes the characteristics of learning another language from the mother tongue (García, 2009). Therefore, it facilitates a conceptual language transfer between home and school language (Cummins, 2000). In this context, the program should promote minority children' academic achievement (Baetens-Beardsmore, 2009). At the same time, bilingual education should be beneficial to language cummins minority children as it makes learning to school content understandable and provides access to their mother tongue (MacSwan and Rolstad, 2010). Because target culture is an important factor during language education and it was stressed that "students would enjoy in language classrooms, at which level they would like to do them their attitudes towards the target culture, the level of importance students attach to the target culture and their understanding of "culture" (Sarıçoban and Çalışkan, 2011, p.7). Submersion programs have a high drop-out rate for language minority pupils who need to learn both school languages and a weak language at the same time (Bialystok, 2001). Because submersion programs disrupt the academic performance and the development of the new language as the students cannot use their own language in the process of understanding the academic material (Cummins, 2000; García, 2009). On the other hand, bilingual programs that teach school materials in both home and school languages also support language minority children's academic achievement and language development (Kimbrough Oller and Eilers, 2002; Lindholm-Leary, 2001).

Bilingual program is a controversial issue, depending on nationalism, migration and multilingualism policies (Petrovic, 1997). Rolstad, Mahoney, Glass stress this issue as "a properly conducted metaanalysis will help provide a true definition of program effects in a wide range of current studies" (2005, p.573-p.274). In this context, one of the problems frequently encountered by meta-analysis in bilingual education is the description and labeling of bilingual program types. European countries receiving a large number of immigrants address bilingual education in many aspects in order to meet the educational needs of both themselves and bilinguals. For example Netherlands the bilingual reception models, which have been applied only in a few schools and Mother Tongue Instruction (MTI), was more widespread and took up as much as $10 \%$ of the time, spent at school (Driessen, 2005, p.75). Sweden, has been trying to establish mother tongue education for children of immigrant background in public schools since the mid-1970s. Therefore, 14 percent of all preschool and school children have a different language other than Swedish (Axelsson, M. 2005, p.108).

Objections and evidence supporting two different views on the advantages and disadvantages of bilingualism have been evaluated. In this context, the number of studies reporting negative outcomes (disadvantages) was found to be more than the number of studies indicating positive results (advantage). These studies are criticized due to reaching the results by small samples, lack of matching variables, and measurement and analysis problems (Alshahrani, 2017). In this research, are focused on these criticisms stressed by Alshahrani. In this context; model, data collection tools, data analysis, and sample size of the research related to bilingualism were investigated. The research process is structured on these topics. Thus, negative and positive criticisms related to bilingualism were investigated by examining the researches. Because the refusal or acceptance of thought about bilingualism must be dependent on the validity of the research conducted in this domain (Alshahrani, 2017). By this way, it is aimed to clarify these criticisms. In this context, the following research questions were examined. 


\subsection{Research questions}

1. How are the focal point and scope of the studies on bilingualism?

2. How are model, data collection tools, data analysis methods and the number of participants of studies on bilingualism?

\section{Method}

In order to reach general conclusions about the characteristics of studies related to bilingualism, general screening model based on examination of sample data taken from the whole or part of the universe has been applied (Karasar, 2013). At the same time, descriptive analysis based on the examination of documents related to a bilingualism subject was used in the research (Yildirim and Şimşek, 2013, p.256-p.258). According to the descriptive analysis, the characteristics (focal point, scope, research model, data collection tools, data analysis method, the samples) of the studies on bilingualism were determined.

\subsection{Sample / Instruments}

The aim of this study is to determine the focal point, scope, research model, data collection tool, data analysis method and sample size of the studies related to bilingualism. Depending on this purpose, the research consists of articles and theses prepared between 2001 and 2019. In order to focus on the studies on bilingualism in the last 20 years this sample studies was selected. The studies have been reviewed by the author and three domain experts in accordance with the criteria. These criteria are given in Table 1.

Table 1. The criteria to review the sample studies.

\begin{tabular}{ll}
\hline Subject of study & Explanation \\
Aim of the study & The purposes of the studies are examined. \\
Research model & Research models used in the process are examined. \\
Data collection tools & The data collection tools used to identify bilingual/bilingualism are examined. \\
Data analysis method & Data analysis methods used to analyze collected data are examined. \\
The sample & The numbers of participants are examined. \\
\hline
\end{tabular}

\subsection{Data collection procedures}

The data were collected from the following databases: ERIC Muş Alparslan University library database and Google Academic databases [Wiley Online Library, Web of Knowledge (ISI), Proquest, PsycNet (APA)], the general network address of YÖK National Thesis Center (https://tez.yok.gov.tr/UlusalTezMerkezi/), ULAKBİM Social Sciences Database and Google Scholar. In order to collect the data, the following keywords were written on the relevant search engine: monolingual, monolingualism, bilingual, bilingualism, bilingual teaching, bilingual training, bilingual education assessment, bilingual learning, and bilingual education. 80 studies collected in these databases were examined according to the determined criteria. As a result, it was determined that 21 of them are not suitable for the aim of the research. In the examination, it was found that one or more sections such as research model, data analysis method, data collection tools sample group and research purpose were not mentioned. These studies were not suitable because of these shortcomings. As a result of the elimination of these studies, 58 studies were examined. 


\subsection{Data analysis}

The sample studies have been reviewed by the author and three domain experts. Criteria in the sample studied were determined by the checklist. The following criteria were established in the checklist.

*The sample study should be done on the bilingualism, bilingual teaching, bilingual training, bilingual education assessment, bilingual learning, and bilingual education

*The sample study should include aims/objectives, methods, data collection tools, data analysis method, and the number of participants

*The sample study should be published in as an article, book, and thesis

*The scope of the sample study should be clear and accessible

*The sample study should be done between 2001 and 2019.

The collected data according to the stages of the descriptive analysis were analyzed by these following steps: Within the scope of these criteria (question) and in accordance with descriptive data analysis stages, a framework for the sample studies has been established. According to the criteria, the themes were determined within the scope of "focal point, scope, research model, data collection tools, data analysis method, the samples". Findings were defined according to the analysis of these themes. In the next step, findings related to the bilingual education were interpreted.

\section{Results}

\subsection{Results of the First Research Question}

In this section, the focal point and scope of the studies related to bilingualism are determined. To determine the focal point and scope, the dependent and independent variables of the sample studies were examined. In this context, the independent variable is a variable assumed to have an effect on another variable (dependent variable). Because of this function, bilingualism and monolingualism factors are determined as an independent variable in the sample studies. The independent variable is linked to the dependent variable in some aspects. Because of this function, the effect of bilingualism and monolingualism on the dimensions (aspects affected by bilingualism and monolingualism) discussed in the sample studies is determined as the dependent variable (Flannelly, Flannelly, and Jankowski, 2014, p. 162-p.163).

Thus, the independent variables of studies on bilingualism and monolingualism factors are coded as the focal point. Accordingly, dependent variables (topics), which are thought to be influenced by bilingualism and monolingualism factors, are coded as the scope. After this association, descriptive analysis was conducted on the sample studies to determine the independent variable (the focal point) and the dependent variable (the scope). The independent variables identified by coding are focal points of the studies. Similarly, the dependent variable determined as a result of the coding indicates the scope of the studies. Thus, the focal point and scope of the studies were determined. The focal points of the studies, which are determined by dependent variables, are grouped as bilingualism, bilingualism and monolingualism, second language (bilingualism). The scope of the studies is listed as language skills (reading, speaking, listening), neural/brain, teaching/learning, working memory, cognitive skills according to the independent variables covering similar aspects (see Table 2). Graph 1 presents the frequency of use of the identified scopes in sample studies. 


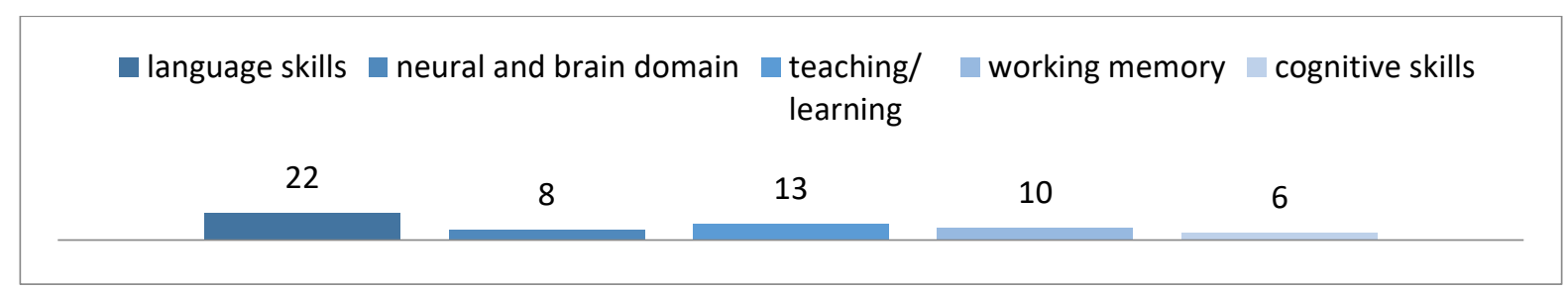

Graph 1. The scope of sample studies related to bilingualism

When Graph 1 is examined, it is seen that most of the studies are done on language skills ( $\mathrm{N}$ : 21). In this context, researchers examined the relation between bilingualism and reading/speaking/listening skills in terms of these aspects: vocabulary, phonological and morphological awareness, word reading, learning to read, different approaches to literacy, understand optimal contexts for reading success, the comprehension of active and passive English sentences, redundant and reliable speech cues, reading difficulties, linguistic abilities and the later development of reading abilities, orthography and phonology in reading aloud, producing words, the comprehension of syntactically simple, receptive vocabulary scores, vocabulary performance, short-term memory skills, reading skills across the languages, multiple measures of executive function, unconscious access to the sound, syntax production, metacognitive awareness, particular patterns of communicative interactions, the development of phonological awareness, the reading, language, memory skills and phonological, reading, spelling, syntactic, working memory tasks and language proficiency and usage. The second scope on which researchers frequently $(\mathrm{N}: 13)$ focus on is the relation between bilingualism and teaching/learning. According to Table 2, the researchers examine the relation between bilingualism and learning/teaching with these aspects: opinions of the first term, satisfying of programs, different test types, ability vocabulary test, digital learning program, successes of learning, the perception of tonal contrasts, function advantages, lexical growth, general creativity and mathematical creativity, creativity in nonmathematical and mathematical problem solving, in executive functioning, grammar learning strategies, proficiency in the foreign language.

The third scope on which researchers frequently focus on is the working memory. The researchers examine the relation between bilingualism and working memory with these aspects: The possible differences, visuospatial and verbal working memory tests, socio-economic status and conflict inhibition and/or working memory underpin the advantage, the organizational structure of working memory and latent mean differences, the architectures of working memory, different levels of working memory, working memory performance, lexical retrieval tasks and executive control tasks, working memory (WM) capacity, influences of task demands and experience on cognitive control and working memory. Although neural / brain and cognitive skills were not studied as frequently as other scopes these scopes were also investigated with different aspects. In particular, the relation between neural / brain and bilingualism is examined with these aspects: neural adaptation, children's neural circuitry, recruiting brain areas, brain structure cortical thickness, brain areas during sentence processing, brain potential, theory of mind (ToM) development, neural activity (single word reading). And the relation between cognitive skills and bilingualism is examined with the following aspects: an array of cognitive skills, the cognitive advantage, cognitive flexibility, cognitive performance in early childhood, influences of task demands and experience on cognitive control and working memory, several possible versions of the inhibition hypothesis. See Table 2 for more details on these results.

\subsection{Results of the Second Research Question}

In this section; the research model, data collection tool, data analysis method and sample size of the studies related to bilingualism were examined. For this reason, sample studies were examined in four 
categories and their relationships with each other were examined. The first of these categories is the research model that researchers use to collect data about bilingualism. In this context, the model of each study was determined and shown chronologically in Table 3. Then the models used in the studies were categorized according to their similarities. Depending on this grouping, the research model used in the sample studies and the frequency of using these models are given in Graph 2.

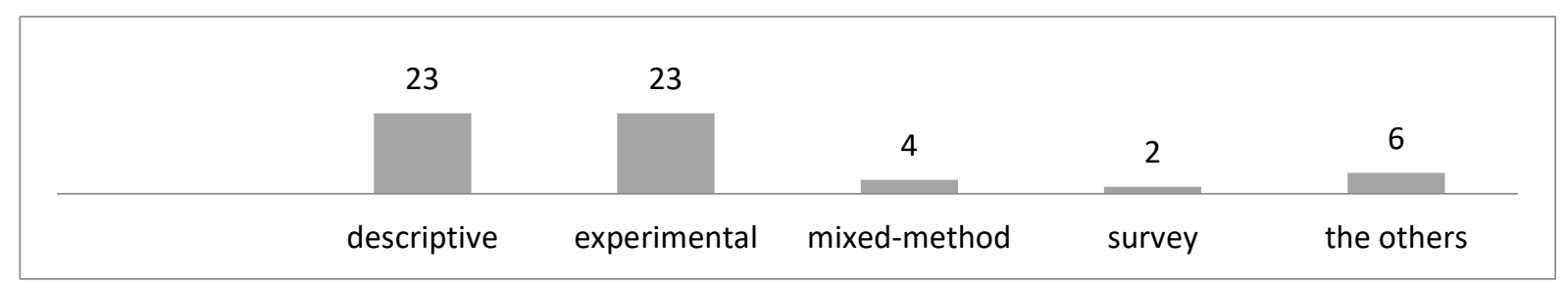

Graph 2. The research models of sample studies

As shown in Graph 2, four models were used in the studies. These are the descriptive, experimental, mixed-method, and survey. Different models than these are grouped as the others. The frequency of use of these models in the sample studies is given in Graph 2. Among them, descriptive and experimental model-based research seems to be more. Mixed-method was less used than the descriptive and experimental model. Other than these, the survey and the other models were used very less. In the descriptive model ( $\mathrm{N}: 23)$, researchers focused on the relation between bilingualism and monolingualism or on the analysis of existing situations related to bilingualism. This finding shows that researchers are more interested in the detection of unclear but effective aspects related to bilingualism and monolingualism. Because there are many ambiguous aspects that need to be solved regarding bilingualism and monolingualism. A similar result is also observed in studies based on the experimental model (N: 23). In this model, the researchers examined the research process related to bilingualism and monolingualism in experiments. Therefore, in order to examine the independent variables in these studies, experimental observation and evaluation of them are in the foreground. The researchers examined the dependent variables related to bilingualism and monolingualism by using mixed-methods according to both qualitative and quantitative data. But this research model is used less $(\mathrm{N}: 4)$. According to this finding, the researchers used either quantitative or qualitative data in the data collection process. In two sample studies, the survey model was used. In these studies, the researchers did a survey about bilingualism and monolingualism. In the others, these models were used with these models: a longitudinal study, demographic information, an event-related method, stratified simple random sampling method, structural equation modeling. Graph 2 shows that these are not frequently used in the sample studies (N: 6).

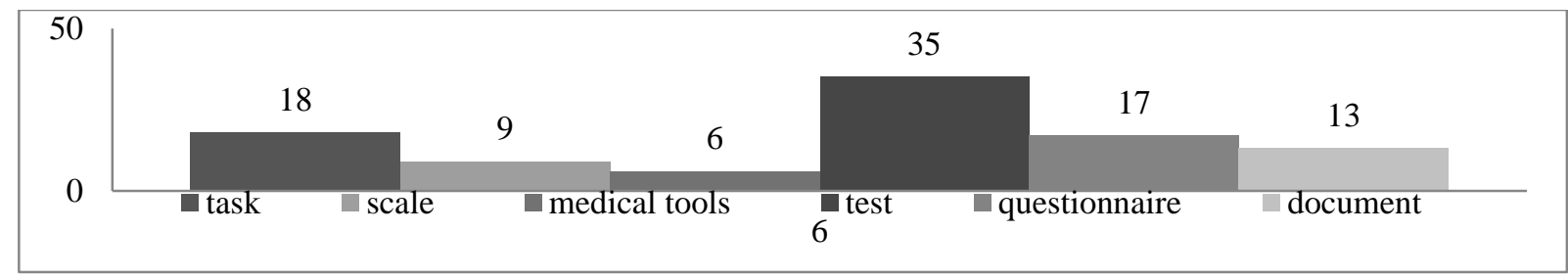

Graph 3. The data collecting tools of sample studies

When the data collection tools used the studies is examined, it is seen that different tools are generally used. The reason why data collection tools differ from research models by number is because of the combined use of multiple different data collection tools in some researches. It is seen more clearly data collection tools are used in different numbers in Graph 3. In particular, tests are the most widely used 
data collection tool in the data collection process. The reason for this is closely related to the model of research. Because in the descriptive, experimental model-based research, achievement test or experimental tests were frequently used as data collection tools ( $\mathrm{N}: 35)$. These tests, which were used in the studies, are mostly pre-test, post-test, and subtest. Apart from these tests, the following tests were used: comprehensive test, vocabulary test, reading tests, digit span, word repetition test, maze memory test, the Torrance tests, verbal ability tests, the working memory test, the verbal (semantic) fluency tests, standardized tests, picture vocabulary test and brief intelligence test, visuospatial tests.

In accordance with the descriptive and experimental models, different tools such as task were used frequently in the data collection process ( $\mathrm{N}$ : 18). These tasks are listed as WM span tasks, digit-span task, standard operation span tasks, non-verbal symmetry span task, EF tasks, picture identification task and picture naming task, the pictorial multiple solution task, mixed conditions on the DCCS task, the pictorial multiple solution task, the creating equal number task, semantic task, theory of mind tasks, the semantic-relatedness tasks, the forward digit span task, memory tasks, working memory tasks. Another data collection tool commonly used in sample studies is the questionnaire (17). Questionnaires were used frequently in researches based on descriptive, mixed-method and survey model. These questionnaires are listed as questionnaire, a language background questionnaire, parental questionnaire, published questionnaire. The data collection tools used in the scope of the document is differentiated according to the purpose and model of the studies. These tools are listed as interview (document), document survey, the toets tweetaligheid, automated working memory assessment, letter identification (decoding), cognitive constructs, abstract reasoning, selective attention and interference suppression, red / blue box crayon box /sticker or change of content, lexical retrieval, verbal ability control measure, internally naming pictures of objects, Videotaped MacArthur CDI data (document).

Scale and medical tools were also used as data collection tools. The frequency of use of these tools is less than the test; task, document, and questionnaire (see Graph 3). This result is closely related to the models of research. The data collection tools used within the scale is specified as picture vocabulary scale, point scale, drawing complexity scale, the Wechsler intelligence scale. In particular, in accordance with the experimental research model, medical tools were used as a data collection tool. These medical tools are listed as infrared spectroscopy neuroimaging, electroencephalography (EEG), Magnetic Resonance (er-fMRI).

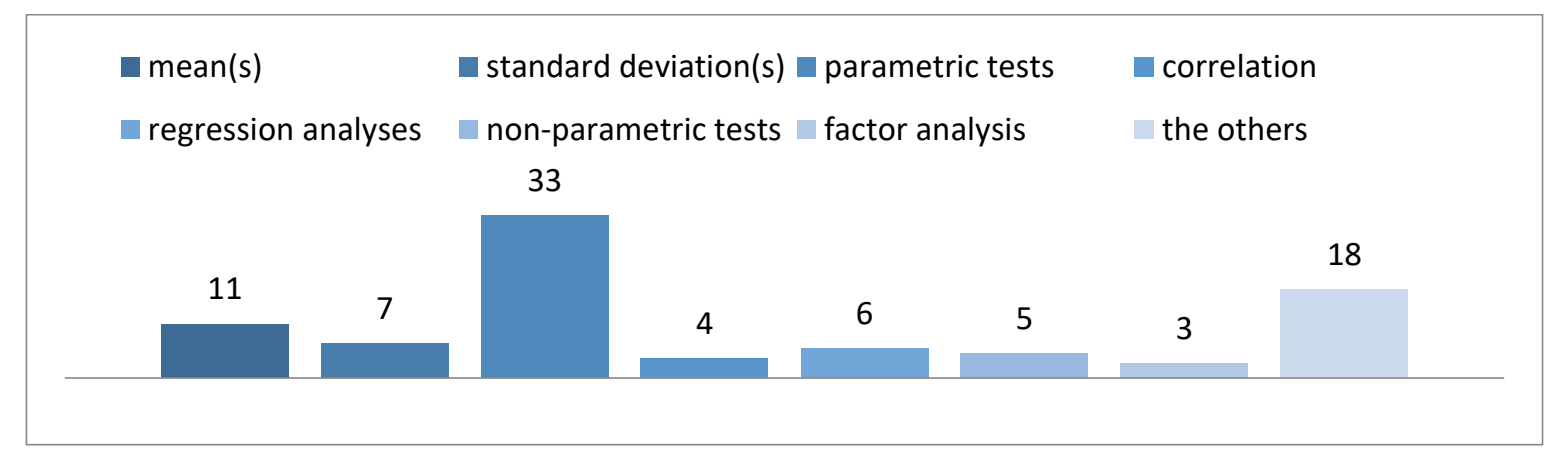

Graph 4. Data analysis methods of sample studies

Another topic discussed in this section is the analysis methods used to analyze data in the research process related to bilingualism and monolingualism. According to Graph 4, different analysis methods were used in the studies depending on the data collection tools. In order to analyze the data, the researchers benefited from the mean, correlation, factor analysis, standard deviation, regression analysis, parametric test, non-parametric test, and the others. When the frequency of their use is considered, it is seen that parametric tests are the most used analyzes (N: 33). In this category, ANOVA analysis was 
used more (N: 16). And t-tests are the second most frequently used parametric tests $(\mathrm{N}: 9)$. These are referred to as ad-hoc t-tests, independent samples t-tests, two-tailed t-test, independent samples t-test. In addition, Pearson, factor and other parametric tests are among the other analyzes used by the researchers. In comparison with the wide use of parametric tests, it is observed that researchers used non-parametric tests less (N: 5). Mann-Whitney U-test, Skew, and Kurtosis, Spearman, separate chisquare analysis are of the analyzes used in this scope. At the same time, it was determined that the mean $(\mathrm{N}: 11)$ and standard deviation (N: 7) analyzes were used generally. In addition, some of the data in the sample studies were analyzed by regression analysis (N: 6).

In comparison with their frequency of use, it is seen that the correlation (4) and factor analysis (3) are less used in the data analysis process. Apart from these analyzes, different analyzes have been used in the sample studies. The following analyzes, which were named as the others, were also frequently used. These are listed as assembled phonology analyses, content analysis, principal component analysis, conjunction analysis, multivariate analysis, percent, meta-analysis, sensitivity analysis, moderator analyses (meta-analysis, sensitivity analysis), the multi-group confirmatory factor analysis, general, the linear model, Matlab-based NIRS-SPM, median reaction, the reanalyzed (the vertical), transcription and coding.

Depending on the findings obtained in this section, a general conclusion can be reached. Research model, data collection tool, and the data analysis method of the sample studies were found to be compatible with each other. Therefore, according to the findings in Graph 2, Graph 3 and Graph 4; the models, data collection tools, and data analysis methods of sample studies related to bilingualism are similar in terms of their characteristics. Their effectiveness, competence, and functionality in the research process related to bilingualism and monolingualism have been evaluated in the discussion section.

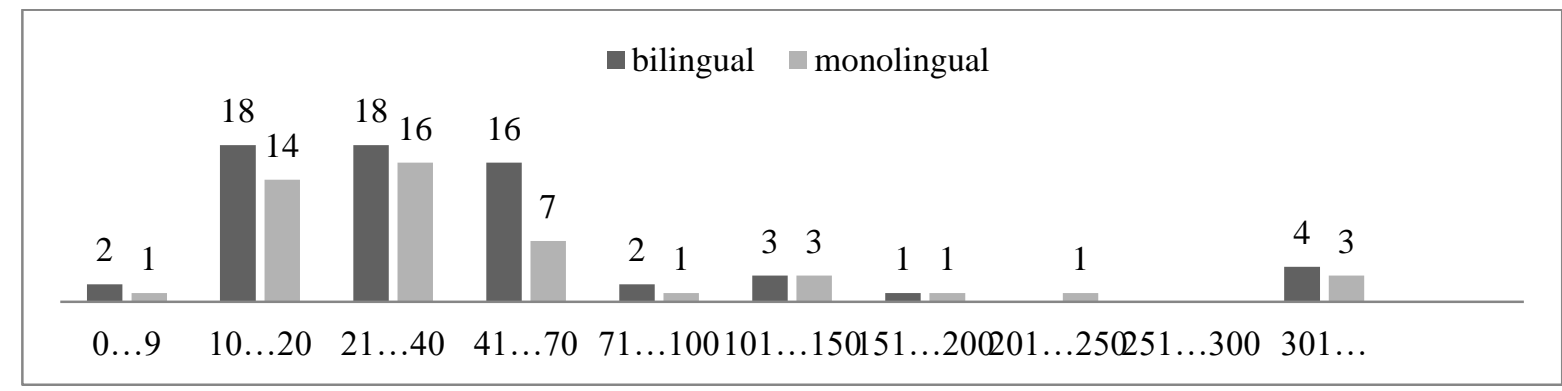

Graph 5. The number of participants of sample studies

In this section, the number of participants in the sample studies was examined to determine the sample characteristics of the studies related to bilingualism and monolingualism. Thus, the number of participants was determined according to descriptive analysis. The results are given in Graph 5. The number of participants in the research was classified according to 9 ranges. The sample sizes were determined as 9-0, 10-20, 21-40, 41-70, 71-100, 101-150, 151-200, 201-250, 251-300 and 301 and above. The number of bilingual and monolingual participants in each range is given separately. Thus, the number of bilingual and monolingual was examined in terms of different or similar aspects. Graph 5 shows that the frequency of the studies in the sample selection ranges mostly consists of 21-40 persons. In this range, the number of bilingual (N: 18) and monolingual (N: 16) did not differ so much. The sample selection frequency was found to be more in the range of 10-20. In this range, the number of bilingual (N: 18) and monolingual (N: 14) did not differ so much too. The third range that is 41-70, with a high number of participants, has a different result. Because, in this range, the number of bilinguals ( $\mathrm{N}$ : 16) and the monolinguals (N: 7) are different from each other. This is due to the fact that this range is 
mostly studied on bilingual individuals. In addition, there are very few participants in the $0-9,71-100$, $101-150,151-200,201-250$ ranges. It was determined that no research was conducted in the range of 251-300 participants. Few studies have been conducted in the last range of 301 and above.

In this section, we investigated the number of participants in the studies related to bilingualism and monolingualism. According to the obtained data, the number of participants is usually stacked in certain number ranges (21-40 and 10-20). At some ranges, the number of participants was found to be quite low. Although the sampling frequency was stacked at some ranges, it was determined that the number of bilingual and monolingual participants in each range was generally close to each other. For more detail see Table 3 about these findings.

\section{Discussion, Conclusion, and Recommendations}

In this research, focal points and the scope of the studies on bilingualism and monolingualism are examined. In order to examine the relations between these two factors, the relations between the dependent and independent variables of the studies was examined. In the sample studies, bilingualism and monolingualism have been identified as the focal points of the independent variables. In this context, the dependent variables, which are affected by bilingualism and monolingualism, are examined as the scope. In the sample studies, it was concluded that the dependent variable was mainly language skills. Therefore, researchers' review scopes about bilingualism and monolingualism are generally on reading, speaking, listening skills. In these studies, the relation between bilingualism and language skills has been examined in many ways (Shih-Ju Hsu, Ip, Arredondo, Tardif and Kovelman, 2019; Patricia, Kuhl, Stevenso, Corrigan, Jasper, Bosch, Deniz Can and Richards, 2016; Jalali-Moghadam and Kormi-Nouri, 2015; Pons, Bosch and Lewkowicz, 2015; Kovelman, Maha Salah-Ud-Din Melody, Beren and Petitto, 2015; Filippi, Morris, Richardson, Bright, Thomas, Karmiloff-Smith and Marian, 2015; AguilarMediavilla, Buil-Legaz, Pérez-Castelló, Rigo-Carratalà and Adrover-Roig, 2014; Kaushanskaya, Blumenfeld and Marian 2011; Carlson, and Meltzoff, 2008; Ransdell, Barbier and Niit, 2006; Berguno and Bowler, 2004; Bialystok, Majumder and Martin, 2003). This result is closely related to the learning and teaching factors. Because the second scope of research that the researcher frequently mentions in sample studies is the relation between bilingualism and teaching/learning. In these studies, it was investigated how an effective teaching/learning process should be realized in bilingualism environments. The main issue in these studies that evaluated the relationship between language skills and education and training is the lack of studies related to the curriculum. In order to improve bilingual learners' language skills, course content, instructional models, course material, measurement, and evaluation processes are required to be prepared in accordance with the bilinguals' learning characteristics and needs. As a matter of fact, this important deficiency was not taken care of in the sample studies. For this reason, in future studies, it is necessary to focus on teaching-learning processes and curriculum development which will support bilinguals' language skills.

The relation between bilingualism and working memory is handled in some aspects cognitively. These scopes, listed as verbal working memory tests, socio-economic status, and conflict inhibition, etc. seem to represent the working memory and cognitive domain sufficiently (Asadollahpour, Baghban, Mirbalochzehi, Naderifar and Tahmasebi, 2015; Nguyen and Astington, 2014; Macnamara and Conway, 2014; Engel de Abreu 2011; Bialystok, Craik and Luk, 2008). The main deficiency in these results is that the relations between dependent variables, language skills, teaching/learning, and working memory are not examined together. In future studies, researchers need to study the effect of bilingualism on the associative dependent variables by the multivariate research model. Thus, firstly, bilingual individuals' needs related to language skills, teaching/learning and working memory will be determined. Then the 
learning and teaching process should be planned according to these needs. There is a need for a lot of experimental studies to be carried out with this perspective.

Depending on the results of the second research question, the model, data collection tools, data analysis methods and the number of participants of the studies were examined. As a result of the study, it is seen that the sample studies generally focus on four models. Among them, descriptive and experimental model-based research is more common; but mixed-method, survey, and the other research models are determined to be less. This is due to the fact that the studies focused on the relations between bilingualism and monolingualism or on the analysis of existing situations related to bilingualism (Hsu, et al. 2019; Jalali-Moghadam and Kormi-Nouri, 2015; Zinszer, Chen, Wu, Shu and Li, 2015; Zhang, Xia and Peng, 2015; Sasisekaran and Weisberg, 2013). In the studies, dependent variables which are within the scope of language skills, teaching/learning, working memory, neural/brain, and cognitive skills have been examined and evaluated experimentally (Hsu, et al. 2016; Ip, Shih-Ju Hsu, Arredondo, Maria, Tardif and Kovelman, 2016; Kaushanskaya and Buac, 2014; Morales, Calvo and Bialystok, 2013; Kaushanskaya, et al. 2011; Proctor, August, Snow and Barr, 2010; Kemp, 2007; Yang, Yang, Ceci, Wang, 2005; Meschyan and Hernandez, 2005). The main deficiency in these studies is the use of methods in which descriptive and experimental studies are generally used for qualitative or quantitative data. But in the first section, seen that bilingualism is a multifaceted phenomenon where many interrelated factors are effective. Because it has many variables as dependent and independent and consists of different aspects. In order to reach more accurate and comprehensive results related to this phenomenon, research should be carried out in which both quantitative and qualitative methods are used together. But it has been determined that the mixed-method, in which these two methods are used together, is less used in sample studies. Therefore, researchers are required to apply more to mixedmethod studies in their future studies. Bilingualism can be examined in a broader context by examining the qualitative and quantitative aspects of dependent variables such as language skills, teaching/learning, working memory, neural/brain, and cognitive skills. Because bilingualism is not a phenomenon with a restricted aspect as stressed before (Moradi, 2014).

Qualitative or quantitative research models also affected the types of data collection tools of the studies. For this reason, tests were used mostly in the data collection process of bilingualism and monolingualism (Jasińska, Berens, Kovelma and Petitto, 2017; Ru-Whui Lee, Chun-Hsien Hsu, ShengKai Lin, Hsien Wu and Jyh-Lang Tzeng 2017; Leikin and Tovli 2014; Sheng, 2014). In accordance with the descriptive and experimental models, tasks were used during the data collection process. Another data collection tool used frequently in sample studies is questionnaire. These results show that quantitative data collection tools are used more widely in the studies. Because researchers have often used quantitative data to study the effects of bilingualism and monolingualism on dependent variables such as language skills, teaching/learning, working memory, neural/brain, and cognitive skills (Kovelman, et al. 2015; Blom, Kuntay, Messer, Verhagen and Leseman, 2014; Macnamara and Conway, 2014).

In the research process related to bilingualism and monolingualism, analysis methods used to analyze the data were examined. ANOVA and t-tests were frequently used in parametric tests. The reason why these two analyzes are more involved in research is related to the research model and data collection tools. Because to examine the effects of bilingualism and monolingualism on dependent variables such as language skills, teaching/learning, working memory, neural/brain, and cognitive skills quantitative data were used. Less quantitative analysis and frequent use of quantitative analyses indicate that researchers focus on specific analyzes in the data analysis process.

In this section, the results of the research process can be concluded as follows: Model, data collection tools, and data analysis methods of the sample studies were found to be compatible with each other in terms of quality and quantity. The following conclusions were reached about their effectiveness, 
competence, and functionality in the research process related to bilingualism and monolingualism. In the studies, dependent variables such as language skills, teaching/learning, working memory, neural/brain, and cognitive skills, which are influenced by the bilingualism and monolingualism, were determined by the qualitative or quantitative way. In future studies, researchers should examine the issue of bilingualism by considering these deficiencies. They should use mixed-method, qualitative and quantitative data collection tools, and multiple data analysis methods together in order to achieve more effective results.

In order to determine the characteristics of the studies related to bilingualism and monolingualism, the number of participants in the sample studies was examined. Thus, it was determined that in which sample group the studies mainly accumulate their participants. Through these findings, it was determined how the number of bilinguals and monolinguals participants is and how close they are to each other quantitatively. The results show that the sample size of the participants of the studies on bilingualism and monolingualism is usually between 10-20 and 21-40. At the same time, it was determined that the number of bilingual and monolingual participants in each range was generally close to each other. In the sample studies, the bilingual and monolingual participant in the control and experimental group should be close to each other quantitatively. Because this feature is the desired and expected result in the sample selection (Özen and Gül, 2007). There is a remarkable point in these results. This point is the difference between the research model/data/collection tools/data analysis method and the number of participants. Specifically, it was seen that there was no correlation between model, data collection tools, data analysis method and the number of participants in sample studies quantitatively (Jasińska, et al. 2017; Rose Ru-Whui Lee, Chun-Hsien Hsu, Sheng-Kai Lin, Hsien Wu and Jyh-Lang Tzeng 2017; Ip, et al. 2016; Patricia, et al. 2016; Filippi, et al. 2015; Leikin and Tovli, 2014; Jasińska and Petitto, 2013; Kaushanskaya, et al. 2011; Golestani, Alario, Meriaux, Le Bihan, Dehaene and Pallier, 2006). The main reason for this is that the number of participants in the research process was not changed much. But a large number of participants should be needed to reach more effective results (Özen, and Gül, 2007, p. 415- p. 416). Because, in order to further examine the characteristics of bilingualism, which is a multifaceted phenomenon, and to further generalize the results achieved, it is necessary to conduct research with larger sample groups. As a matter of fact, this result justifies the criticisms made before on this topic. Because in the previous research this problem situation has been criticized as reaching general conclusions based on small samples, insufficiency of matching variables determined in sample studies and frequent use of similar measurements and analyzes (Alshahrani, 2017).

To address the issue of bilingualism from a wider perspective, and to reach general conclusions based on both qualitative and quantitative data, researchers need to focus on research with a larger number of participants. Because research with larger samples may reveal other dependent variables that cannot be determined until now. At the same time, the results will provide the researcher with a more generalized evaluation of the findings. Thus, a large number of the sample will allow the researcher to examine an idea about bilingualism more objectively. This factor will make clear the highlighted criticisms related to rejecting the idea (the negative effect of bilingualism) or accepting the idea (the positive effect of bilingualism).

\section{References}

Adesope, O. O., Lavin, T., Thompson, T., \& Ungerleider, C. (2010). A systematic review and metaanalysis of the cognitive correlates of bilingualism. Review of Educational Research, 80, 207-245. 
Akınc1, M. A. (2006). Du bilinguisme à la bilittéracie. Comparaison entre élèves bilingues turcsfrançais et élèves monolingues français. Langage et société, 2006/2 (n 116).

Alshahrani, A. (2017). Effect of bilingualism on the development of cognitive processes among children. Arab World English Journal (AWEJ), 8 (4), 451-466.

Axelsson, M. (2005). Mother Tongue Teaching and Programs for Bilingual Children in Sweden. The Effectiveness of Bilingual School Programs for Immigrant Children. Wissenschaftszentrum Berlin für Sozialforschung (WZB), Veröffentlichung der Arbeitsstelle Interkulturelle Konflikte und gesellschaftliche Integration (AKI) p.108-122.

Baetens-Beardsmore, H. (2009). Bilingual education: Factors and variables. In O. García (Ed.), Bilingual education in the 21st century: A global perspective (pp. 137-159). Malden, MA: WileyBlackwell.

Baker, C. (2001). Foundations of bilingual education and bilingualism, bilingual education and bilingualism (Baker, C. $3^{\text {rd }}$ edition). Multilingual Matters Ltd. Clevedon, Buffalo, Toronto, Sydney, 134-162.

Barac, R. \& Bialystok, E. (2016). Cognitive development of bilingual children. Language Teaching, $44(01), 36-54$.

Bialystok, E. (2001). Bilingualism in development. Language, literacy and cognition. New York, NY: Cambridge University Press.

De Houwer, A. (2005). Early bilingual acquisition: focus on morphosyntax and the separate development hypothesis. Communication Department, Universiteit Antwerpen, Antwerpen, Belgium.

Driessen, G. 2005. From cure to curse: the rise and fall of bilingual education programs in the Netherlands. the effectiveness of bilingual school programs for immigrant children.

Wissenschaftszentrum Berlin für Sozialforschung (WZB), Veröffentlichung der Arbeitsstelle Interkulturelle Konflikte und gesellschaftliche Integration (AKI) p.76-107.

Flannelly, L. T., Flannelly, K. J. \& Jankowski, K. R. B. (2014). Independent, dependent, and other variables in healthcare and chaplaincy research. independent, dependent, and other variables in healthcare and chaplaincy research. Journal of Health Care Chaplaincy, (20)4, 161-170.

García, O. (2009). Bilingual education in the 21st century: A global perspective. Oxford, England: Wiley-Blackwell.

Gogoli, I. (2005). Bilingual education - the German experience and debate. the effectiveness of bilingual school programs for immigrant children. Wissenschaftszentrum Berlin für Sozialforschung (WZB), Veröffentlichung der Arbeitsstelle Interkulturelle Konflikte und gesellschaftliche Integration (AKI) p.133-145.

Grundy, G. J. \& Timmer, K. (2017). Bilingualism and working memory capacity: A comprehensive meta-analysis. Second Language Research, 33(3), 325-340.

Hakuta, K., \& Mostafapour, E. F. (1996). Perspectives from the history and politics of bilingualism and bilingual education in the United States. In I. Parasnis (Ed.)

Jasinska, K.K. \& Petitto, L.A. (2013). How the age of bilingual exposure can change the neural systems for language in the developing brain: A functional near-infrared spectroscopy investigation of syntactic processing in monolingual and bilingual children. Developmental Cognitive Neuroscience, 6, 87-101. 
Karasar, N. (2002). Bilimsel araştırma yöntemi. Ankara: Nobel Yayın Dağıtım.

Kimbrough Oller, D, \& Eilers, R. E. (Eds.). (2002). Language and literacy in bilingual children. Clevedon, England: Multilingual Matters.

Lindholm-Leary, K. L. (2001). Dual language education. Clevedon, England: Multilingual Matters.

MacSwan, J., \& Rolstad, K. (2010). The role of language in theories of academic failure for linguistic minorities. In J. Petrovic (Ed.), International perspectives on bilingual education: Policy, practice, and controversy (pp. 173-193). Charlotte, NC: Information Age.

Moradi, H. (2014). An investigation through different types of bilinguals and bilingualism. International Journal of Humanities \& Social Science Studies (IJHSSS). I (II), 107-112.

Özen, Y.\& Gül, A. (2007). Population-sampling issue on social and educational research studies. [KKEFDI]OKKEF, 1, 394-422.

Petrovic, J. (1997). Balkanization, bilingualism, and comparisons of language situations at home and abroad. Bilingual Research Journal, 2, 233-254.

Reljić, G., Ferring, D. \& Martin, R. (2016). A meta-analysis on the effectiveness of bilingual programs in Europe. Review of Educational Research Month, 201(XX, X), 1-.37.

Rolstad, K., Mahoney, K. S. \& Glass, G. V. (2005). Weighing the evidence: a meta-analysis of bilingual education in Arizona. Bilingual Research Journal, 29(1), 43-p67.

Rolstad, K., Mahoney, K., \& Glass, G. (2005). The big picture: A meta-analysis of program effectiveness research on English language learners. Educational Policy, 19, 572-594.

Sarıçoban, A. \& Çalışkan, G. (2011). The influence of target culture on language learners. Journal of Language and Linguistic Studies. 7(1), 7-17.

Schmit, M. Köpke, B., Keijzer, M. \& Weilemar, L. (2012). First language attrition: Interdisciplinary perspectives on methodological issues. Proceedings of the 1 st International Conference on First Language Attrition, Amsterdam, Aug. 2002.

Sebastian, R., Laird, A. \& Kiran, S. (2011). Meta-analysis of the neural representation of first language and second language. Applied Psycholinguistics, 32(4), 799-819.

Vallet, L.-A., \& Caille, J.-P. (2000). - "La scolarité des enfants d'immigrés" in VAN ZANTEN A. (dir.), L'école : l'état des savoirs, Paris, La Découverte, pp. 293-301.

Yıldırım, A. \& Şimşek, H. (2013). Sosyal bilimlerde nitel araştırma yöntemleri. Seçkin, Ankara.

\section{References of the Data Collection}

Abu-Rabia, S. \& Siegel, L. S. (2002). Reading, syntactic, orthographic, and working memory skills of bilingual Arabic-English speaking Canadian children. Journal of Psycholinguistic Research, 31, 661-678.

Abutalebi, J., Della Rosa, P.A., Gonzaga, A.K.C., Keim, R., Costa, A., \& Perani, D. (2013). The role of the left putamen in multilingual language production. Brain Lang., 125 (3), 307-315.

Adi-Japha, E., Berberich-Artzi, J. \& Libnawi, A. (2010). Cognitive flexibility in drawings of bilingual children. Child Development 81, 1356-66.

Aguilar-Mediavilla, E., Buil-Legaz, L., Perez-Castello, J. A., Rigo-Carratala, E., \& Adrove Roig, D. (2014). Early preschool processing abilities predict subsequent reading outcomes in bilingual 
Spanish-Catalan children with specific language impairment (SLI). Journal of Communication Disorders, 50, 19-35.

Asadollahpour, F., Baghban, K., Mirbalochzehi, P., Naderifar, E. \& Tahmasebi, B. (2015). The performance of bilingual and monolingual children on working memory tasks. Iranian Rehabilitation Journal, 13 (3), 53-57.

Berguno, G. \& M. Bowler, D. (2004). Communicative interactions, knowledge of a second language, and theory of mind in young children. The Journal of Genetic Psychology, 165(3), 293-309.

Bialystok, E. \& Luk, G. (2012). Receptive vocabulary differences in monolingual and bilingual adults. Bilingualism, Language and Cognition, 15, 397-401.

Bialystok, E., Craik, F. \& Luk, G. (2008). Cognitive control and lexical access in younger and older bilinguals. Journal of Experimental Psychology: Learning, memory, and cognition, 34, 859.

Bialystok, E., Majumder, S. \& Martin, M. M. (2003). Developing phonological awareness: Is there a bilingual advantage? Applied Psycholinguistics, 24, 27-44.

Blom, E., Kuntay, A.C., Messer, M., Verhagen, J. \& Leseman, P. (2014). The benefits of being bilingual: Working memory in bilingual Turkish-Dutch children. Journal of Experimental Child Psychology, 128, 105-19.

Carlson, S.M. \& Meltzoff, A.N. (2008). Bilingual experience and executive functioning in young children. Developmental Science, 11(2), 282-298.

Colzato, L. S., Bajo, M. T., van den Wildenberg, W., Paolieri, D., Nieuwenhuis, S., La Heij, W. \& Hommel, B. (2008). How does bilingualism improve executive control? A comparison of active and reactive inhibition mechanisms. Journal of Experimental Psychology: Learning, Memory, and Cognition, 34, 302-312.

D'Angiulli, A., Siegel, L.S. \& Serra, E. (2001). The development of reading in English and Italian in bilingual children. Appl. Psycholinguist, 22 (4), 479-507.

De Bleser, R., Dupont, P., Postler, J., Bormans, G., Speelman, D., Mortelmans, L. \& Debrock, M. (2003). The organization of the bilingual lexicon: a PET study. Journal of Neurolinguistics, 16, 439-456.

Demie, F. \& Strand, S. (2006). English language acquisition and educational attainment at the end of secondary school. Educational Studies, 32, 215-231.

Demirdöven, G. H. \& Okur, A. (2017). İki dilli Türkçe öğretmeni adaylarının iki dillilik olgusuna yönelik görüşleri (Duisburg/Essen Üniversitesi örneği). Ana Dili Eğitimi Dergisi, 5(4), 774-805.

Engel de Abreu, P.M. (2011). Working memory in multilingual children: Is there a bilingual effect? Memory, 19, 529-37.

Engel de Abreu, P.M.E., Cruz-Santos, A., Tourinho, C. J., Martin, R., \& Bialystok, E. (2012). Bilingualism enriches the poor: Enhanced cognitive control in low-income minority children. Psychological Science, 23, 1364-71.

Filippi, R., Leech, R., Thomas, M.S., Green, D.W. \& Dick. F. A. (2012). Bilingual advantage in controlling language interference during sentence comprehension. Bilingualism: Language and Cognition, (15), 858-872. 
Filippi, R., Morris, J., Richardson, F. M., Bright, P., Thomas, M. S., Karmiloff-Smith, A., \& Marian, V. (2015). Bilingual children show an advantage in controlling verbal interference during spoken language comprehension. Bilingualism: Language and Cognition, 18(3), 490-501.

Golestani, N., Alario, F., Meriaux, S., Le Bihan, D., Dehaene, S., \& Pallier, C. (2006). Syntax production in bilinguals. Neuropsychologia, 44, 1029-1040.

Hsu, S.-J. L., Ip, Ka I. Arredondo, M. M., Tardif, T., \& Kovelman, I. (2019). Simultaneous acquisition of English and Chinese impacts children's reliance on vocabulary, morphological and phonological awareness for reading in English. International Journal of Bilingual Education and Bilingualism, 22 (2), 207-223.

Ip, K. I., Hsu, L. S.-J., Arredondo, M. M., Tardif, T., \& Kovelman, I. (2016). Brain bases of morphological processing in Chinese-English bilingual children. Developmental Science, 1-17.

Jalali-Moghadam, N., \& Kormi-Nouri, R. (2015). The role of executive functions in bilingual children with reading difficulties. Scandinavian Journal of Psychology, 56(3), 297-305.

Jasińska, K.K., \& Petitto, L.A. (2013). How age of bilingual exposure can change the neural systems for language in the developing brain: a functional near-infrared spectroscopy investigation of syntactic processing in monolingual and bilingual children. Dev. Cogn. Neurosci., 6, 87-101.

Jasińska, K.K., Berens, M.S., Kovelma, I., \& Petitto, L.A. (2017). Bilingualism yields languagespecific plasticity in left hemisphere's circuitry for learning to read in young children. Neuropsychologia, 98 (2017) 34-45.

Kaushanskaya, M., Blumenfeld, H.K., \& Marian, V. (2011). The relationship between vocabulary and short-term memory measures in monolingual and bilingual speakers. International Journal of Bilingualism, 15, 408-425.

Kaushanskaya, M., Gross. M., \& Buac, M. (2014). Effects of classroom bilingualism on taskshifting, verbal memory, and word learning in children. Developmental Science, 17, 564-83.

Kemp, C. (2007). Strategic processing in grammar learning: Do multilingual use more strategies? International Journal of Bilingualism, 4, 241-261.

Keshavarz, M. H., \& Astaneh, H. (2004). The impact of bilinguality on the learning of English vocabulary as a foreign language (L3). International Journal of Bilingual Education and Bilingualism, 7, 295-302.

Klein, D., Mok, K., Chen, J.-K. \& Watkins, K. E. (2013). Age of language learning shapes brain structure: A cortical thickness study of bilingual and monolingual individuals. Brain \& Language, $131,20-24$.

Kovelman, I., Salah-Ud-Din M., S. Beren, M. \& Petitto, L.-A. (2015). "One glove does not fit all" in bilingual reading acquisition: Using the age of first bilingual language exposure to understand optimal contexts for reading success. Cogent Education, (2015), 2.

Kremin, L. V., Arredondo, M. M., Hsu, L. S.-J., Satterfield, T. \& Kovelman, I. (2016). The effects of Spanish heritage language literacy on English reading for Spanish-English bilingual children in the US. International Journal of Bilingual Education and Bilingualism, 22 (2), 192-206.

Kuhl, P. K., Stevens, J., Corrigan, N. M., van den Bosch, J. J.F., Deniz Can, D., \& Richards, T. (2016). Neuroimaging of the bilingual brain: Structural brain correlates of listening and speaking in a second language. Brain \& Language, 162, 1-9. 
Leikin, M., \& Tovli, E. (2014). Bilingualism and creativity in early childhood. Creativity Research Journal, 26: 411-17.

Luk, G., \& Bialystok, E. (2013). Bilingualism is not a categorical variable: Interaction between language proficiency and usage. Journal of Cognitive Psychology, 25, 605-21.

Macnamara, B. N., \& Conway, A. R. (2014). Novel evidence in support of the bilingual advantage: Influences of task demands and experience on cognitive control and working memory. Psychonomic Bulletin \& Review, 21(2), 520-525.

Meschyan, G., \& Hernandez, A. E. (2005). Impact of language proficiency and orthographic transparency on bilingual word reading: An fMRI investigation. NeuroImage, 29, 1135 - 1140.

Morales, J., Calvo, A. \& Bialystok, E. (2013). Working memory development in monolingual and bilingual children. Journal of Experimental Child Psychology, 114, 187-202.

Nguyen, T.K., \& Astington, J.W. (2014). Reassessing the bilingual advantage in the theory of mind and its cognitive underpinnings. Bilingualism: Language and Cognition, 17, 396-409.

Oller, D. K., Pearson, B. Z. \& Cobo-Lewis, A. B. (2007). Profile effects in early bilingual language and literacy. Applied Psycholinguistics, 28, 191-230.

Paap, K. R. \& Sawi, O. (2014). Bilingual advantages in executive functioning: problems in convergent validity, discriminant validity, and the identification of the theoretical constructs. Front. Psychol., 2014 | https://doi.org/10.3389/fpsyg.2014.00962.

Patrick Proctor, C., August, D., Snow, C., \& Barr, C. D. (2010). The interdependence continuum: a perspective on the nature of Spanish-English bilingual reading comprehension. Bilingual Research Journal, 33 (1), 5-20.

Petitto, L. A. (2001). Bilingual signed and spoken language acquisition from birth: implications for the mechanisms underlying early bilingual language acquisition. J. Child Lang., 28, 453-496.

Pons F, Bosch, L. \& Lewkowicz, D.J. (2015). Bilingualism modulates infants' selective attention to the mouth of a talking face. Psychological Science, 26, 490-98.

Ransdell, S., Barbier, M., \& Niit, T. (2006). Metacognitions about language skill and working memory among monolingual and bilingual college students: When does multilingualism matter? International Journal of Bilingual Education and Bilingualism, 9, 728-741.

Ratiu, I., \& Azuma, T. (2015). Working memory capacity: Is there a bilingual advantage? Journal of Cognitive Psychology, 27: 1-11.

Ru-Whui Lee, R., Hsu, C.-H., Lin, S.-K., Wu, D. H., \& Tzeng, O. J.-L. (2017). Learning transforms functional organization for Mandarin lexical tone discrimination in the brain: Evidence from a MEG experiment on second language learning. Journal of Neurolinguistics 42, 124-139.

Sasisekaran, J., \& Weisberg, S. (2013). The effects of cognitive: Linguistic variables and language experience on behavioral and kinematic performances in nonword learning. Journal of Psycholinguistic Research, 42, 175-90.

Şen, Ü. (2016). The problem of teacher education in teaching Turkish to bilingual Turkish children and an evaluation of the current situation in universities. Ana Dili Eğitimi Dergisi, 4(4), 518-529.

Sheng, L. (2014). Lexical-semantic skills in bilingual children who are becoming English-dominant: A longitudinal study. Bilingualism: Language and Cognition, 17 (3), 556-571. 
Smithson, L., \& Nicoladis E. (2013). Verbal memory resources predict iconic gesture use among monolinguals and bilinguals. Bilingualism: Language and Cognition, 16, 934-44.

Soliman, A.M. (2014). Bilingual advantages of working memory revisited: A latent variable examination. Learning and Individual Differences, 32,168-77.

Sung, K.-Y. (2013). L2 motivation in foreign language learning. Journal of Language and Linguistic Studies, 9(2), 19-30.

Timmer, K., Ganushchak, L.Y., Ceusters, I., \& Schiller, N.O. (2014). Second language phonology influences first language word naming. Brain and Language, 133, 14-25.

Wu, Y.J., \& Thierry, G. (2010). Chinese-English bilinguals reading English hear Chinese. The Journal of Neuroscience, 30, 7646-51.

Yang, H., Yang, S., Ceci, S., \& Wang, Q. (2005). Effects of bilinguals' controlled attention on working memory and recognition. In J. Cohen, K. McAlister, K. Rolstad, \& J. MacSwan (Eds.). Proceedings of the 4th international symposium on bilingualism, Somerville, MA: Cascadilla Press.

Zinszer, B. D., Chen, P., Wu, H., Shu, H., \& Li, P. (2015). Second language experience modulates neural specialization for first language lexical tones. Journal of Neurolinguistics, 33, 50-66.

\section{Appendix}

Table 2. The focal point and scope of studies on bilingualism according to independent and dependent variables

\begin{tabular}{|c|c|c|}
\hline $\begin{array}{l}\text { Independent } \\
\text { variable/focal } \\
\text { point }\end{array}$ & Dependent variable/scope & The scope of studies \\
\hline \multirow{4}{*}{$\begin{array}{l}\text { bilinguals and } \\
\text { monolinguals }\left(\mathrm{S}^{\mathrm{b}} 1\right) \\
\text { bilingual and } \\
\text { monolingual children } \\
\text { (S5) bilingual and } \\
\text { monolingual }\end{array}$} & \multirow{19}{*}{$\begin{array}{l}\text { language skills } \\
\text { (reading/speaking/listening) }\end{array}$} & *on their English language and reading skills including \\
\hline & & $\begin{array}{l}\text { vocabulary, phonological and morphological awareness, } \\
\text { and word reading. }\end{array}$ \\
\hline & & *phonological and orthographic representations during \\
\hline & & English reading. \\
\hline $\begin{array}{l}\text { bilingual (S7) } \\
\text { bilingual (S8) }\end{array}$ & & *on their English language and reading skills including \\
\hline bilinguals $\quad(\mathrm{S} 10)$ & & vocabulary, phonological and morphological awareness, \\
\hline monolinguals (S12) & & and word reading. \\
\hline bilinguals and & & * children's neural circuitry for learning to read \\
\hline $\begin{array}{l}\text { monolinguals (S15) } \\
\text { bilingualism (S17) }\end{array}$ & & *relationships between white matter structure and \\
\hline second language (L2) & & naturalistic immersive experience in listening to and \\
\hline (S24) multilingual & & speaking English \\
\hline (S27) bilinguals and & & *children's age of first bilingual exposure can interact with \\
\hline monolingual and & & different approaches to literacy (understand optimal \\
\hline bilingual $\quad(\mathrm{S} 36)$ & & contexts for reading success) \\
\hline bilingual and & & * the comprehension of active and passive English sentences \\
\hline $\begin{array}{l}\text { monolingual (S3/) } \\
\text { bilingual (S40) }\end{array}$ & & * to keep languages apart increases their attention to the \\
\hline bilinguals (S44) & & mouth as a source of redundant and reliable speech cues \\
\hline bilinguals (S45) & & * the joint effect of reading difficulties (RD) and \\
\hline monolinguals (S47) & & bilingualism on executive functions \\
\hline
\end{tabular}

${ }^{\mathrm{b} S}$ : Study 


\begin{tabular}{|c|c|c|}
\hline \multirow{26}{*}{$\begin{array}{l}\text { (L1) and second (L2) } \\
\text { (S52) monolingual } \\
\text { and bilingual (S53) } \\
\text { second language } \\
\text { (S56) monolingual } \\
\text { and bilingual (S58) } \\
\text { bilingual (S33) }\end{array}$} & & *the relationship between preschool cognitive and linguistic \\
\hline & & abilities and the later development of reading abilities. \\
\hline & & *phonology is active during L1 reading and the contributions \\
\hline & & of orthography and phonology in reading aloud \\
\hline & & * engaged when producing words in the less proficient \\
\hline & & language. \\
\hline & & * the comprehension of syntactically simple with more \\
\hline & & complex sentences \\
\hline & & * English receptive vocabulary scores \\
\hline & & * on their native-language vocabulary performance, and \\
\hline & & short-term memory skills and vocabulary performance \\
\hline & & * reading skills across the languages (interdependence, \\
\hline & & falling along a continuum mediated by the commonalities \\
\hline & & between Spanish and English.) \\
\hline & & * unconscious access to the sound form of Chinese words \\
\hline & & (read or listen to English words) \\
\hline & & * multiple measures of executive function by administering a \\
\hline & & battery of tasks \\
\hline & & * the functional correlates of syntactical processing (syntax \\
\hline & & production) \\
\hline & & $\begin{array}{l}\text { * metacognitive awareness, as measured by self-ratings of } \\
\text { reading, writing, speaking and listening skills }\end{array}$ \\
\hline & & *the effect that particular patterns of communicative \\
\hline & & interactions \\
\hline & & * the development of phonological awareness \\
\hline & & * the factors that realistic representation (language \\
\hline & & proficiency and usage) \\
\hline $\begin{array}{l}\text { bilingual (S2) } \\
\text { bilingual (S7) and } \\
\text { bilingual } \\
\text { monolingual (S29) } \\
\text { monolinguals and } \\
\text { bilinguals (S32) } \\
\text { bilingual and } \\
\text { monolingual (S34) } \\
\text { bilingual (S41) } \\
\text { bilingual and } \\
\text { monolingual (S43) } \\
\text { bilingual (S54) }\end{array}$ & $\begin{array}{l}\text { neural and brain } \\
\text { domain }\end{array}$ & $\begin{array}{l}\text { * neural adaptation may vary as a function of structural and } \\
\text { orthographic characteristics of bilinguals' two languages } \\
\text { * children's neural circuitry for learning to read } \\
\text { * recruiting brain areas during sentence processing } \\
\text { *on brain structure cortical thickness } \\
\text { * brain areas during sentence processing } \\
\text { * functional magnetic resonance imaging (fMRI) and event-related } \\
\text { brain potential } \\
\text { * theory of mind (ToM) development } \\
\text { * how language proficiency and orthographic transparency (letter } \\
\text { sound mapping consistency) modulate neural activity (single word } \\
\text { reading) }\end{array}$ \\
\hline $\begin{array}{l}\text { bilingual (S9) } \\
\text { monolingual and } \\
\text { bilingual (S49) } \\
\text { bilingual and } \\
\text { monolingual (S57) } \\
\text { second language (S4) } \\
\text { second language } \\
\text { learners (S13) second } \\
\text { language learners } \\
\text { (S14) bilinguals, } \\
\text { monolinguals (S16) } \\
\text { bilingual (S18) } \\
\text { bilingualism (S19) } \\
\text { bilingualism (S23) } \\
\text { bilingual and } \\
\text { monolingual (S28) } \\
\text { multilingual (S51) } \\
\text { bilingualism (S59) }\end{array}$ & $\begin{array}{l}\text { teaching and } \\
\text { learning }\end{array}$ & $\begin{array}{l}\text { * in terms of the programs' satisfying the demand and the relevance } \\
\text { of their content } \\
\text { * different test types (provided a clear demonstration of "profile } \\
\text { effects,") } \\
\text { * on a controlled productive ability vocabulary test } \\
\text { * a short term digital learning program, and were found to have } \\
\text { improved sensitivity in discrimination for lexical tones by } \\
\text { developing a left-lateralized dominance } \\
\text { * identifying differences in brain changes that reflect successes of } \\
\text { learning } \\
\text { * pattern of activation in the perception of tonal contrasts. } \\
\text { * having certain executive function advantages } \\
\text { * how age and initial language proficiency are related to lexical } \\
\text { growth } \\
\text { *on the development of general creativity and mathematical } \\
\text { creativity. } \\
\text { * on creativity in nonmathematical and mathematical problem } \\
\text { solving } \\
\text { * in executive functioning (EF): antisaccade, attentional network } \\
\text { test, Simon, and color-shape switching }\end{array}$ \\
\hline
\end{tabular}




\begin{tabular}{|c|c|c|}
\hline & & $\begin{array}{l}\text { *the use of grammar learning strategies } \\
\text { * proficiency in the foreign language such that cognate items are a } \\
\text { measure of higher mastery than non-cognate ones }\end{array}$ \\
\hline $\begin{array}{l}\text { monolingual and } \\
\text { bilingual (S11) } \\
\text { bilingual, } \\
\text { monolingual (S20) the } \\
\text { bilingual (S22) } \\
\text { bilinguals and } \\
\text { monolinguals (S25) } \\
\text { monolinguals and } \\
\text { bilinguals (S30) } \\
\text { monolingual and } \\
\text { bilingual (S31) } \\
\text { bilingualism (S39) } \\
\text { monolinguals and } \\
\text { bilinguals (S46) } \\
\text { bilinguals (S55) } \\
\text { bilingualism (S26) }\end{array}$ & working memory (WM) & $\begin{array}{l}\text { *the possible differences in the working memory } \\
\text { * on visuospatial and verbal working memory tests } \\
\text { * considering socioeconomic status and conflict inhibition and/or } \\
\text { working memory underpin the advantage } \\
\text { * the organizational structure of working memory (WM) and latent } \\
\text { mean differences in WM components } \\
\text { *whether the architectures of working memory differ whether } \\
\text { individual differences in working memory predict gesture use. } \\
\text { * on tasks requiring different levels of working memory } \\
\text { * working memory performance } \\
\text { * on working memory tasks, on lexical retrieval tasks, and on } \\
\text { executive control tasks } \\
\text { * working memory (WM) capacity by controlling their attention } \\
\text { well on an attention-impeded Stroop-span task while undergoing } \\
\text { constant interference } \\
\text { *the interplay between (a) the magnitude of bilingual management } \\
\text { demands and (b) the amount of experience managing those } \\
\text { demands. (Influences of task demands and experience on cognitive } \\
\text { control and working memory) }\end{array}$ \\
\hline $\begin{array}{l}\text { bilingual (21) } \\
\text { bilingualism (S38) } \\
\text { bilingual and } \\
\text { monolingual (S42) } \\
\text { second language (L2) } \\
\text { (S50) bilingualism } \\
\text { (S26) monolinguals } \\
\text { and bilinguals (S48) }\end{array}$ & cognitive skills & $\begin{array}{l}\text { * on an array of cognitive skills. } \\
\text { * the cognitive advantage (poverty and, if it does, which specific } \\
\text { processes are most affected) } \\
\text { * cognitive flexibility (draw a flower and a house that do not exist) } \\
\text { *cognitive performance in early childhood (the ideas of proponents } \\
\text { and opponents) } \\
\text { *the interplay between (a) the magnitude of bilingual management } \\
\text { demands and (b) the amount of experience managing those } \\
\text { demands. (influences of task demands and experience on cognitive } \\
\text { control and working memory) } \\
\text { * several possible versions of the inhibition hypothesis (stop the } \\
\text { signal performance, inhibition of return, and the attentional blink) }\end{array}$ \\
\hline
\end{tabular}

Table 3. The method, data analysis model, data collection tools and the participants of the sample studies.

\begin{tabular}{|c|c|c|c|c|}
\hline $\begin{array}{l}\text { Researcher, } \\
\text { year }\end{array}$ & Study model & Data collection tools & Data analysis methods & $\begin{array}{l}\text { The number of } \\
\text { participants }\end{array}$ \\
\hline $\begin{array}{l}\text { Hsu Shih-Ju et } \\
\text { al. (2019) }\end{array}$ & descriptive & questionnaire & $\begin{array}{l}\text { means and standard } \\
\text { deviations, ad-hoc t- } \\
\text { tests }\end{array}$ & $\begin{array}{l}77 \text { English monolinguals } \\
\text { and } 57 \text { Chinese-English } \\
\text { bilinguals }\end{array}$ \\
\hline $\begin{array}{l}\text { Jasińska et al. } \\
\text { (2017) }\end{array}$ & experimental & $\begin{array}{l}\text { functional Near Infrared } \\
\text { Spectroscopy } \\
\text { neuroimaging }\end{array}$ & $\begin{array}{l}\text { Phonological analyses } \\
\text { and hypoactivation in } \\
\text { left frontal regions } \\
\text { associated r with } \\
\text { assembled phonology }\end{array}$ & $\begin{array}{l}26 \text { Spanish-English and } \\
\text { French-English bilinguals } \\
\text { and monolingual }\end{array}$ \\
\hline $\begin{array}{l}\text { Demirdöven et } \\
\text { al. (2017) }\end{array}$ & descriptive & interview (document) & content analysis & $\begin{array}{l}12 \text { were acquired German } \\
\text { and } 1 \text { student Turkish }\end{array}$ \\
\hline $\begin{array}{l}\text { Ru-Whui Lee, } \\
\text { et al. (2017) }\end{array}$ & experimental & the pre- and post-test & $\begin{array}{l}\text { principle component } \\
\text { analysis }\end{array}$ & 18 foreign students \\
\hline $\begin{array}{l}\text { Kremin et al. } \\
(2016)\end{array}$ & descriptive & $\begin{array}{l}\text { the questionnaire, Elision } \\
\text { subtest from the } \\
\text { Comprehensive Test } \\
\text { Verbal Knowledge } \\
\text { subtest from KBIT-2, } \\
\text { Receptive One-Word } \\
\text { Picture Vocabulary Test }\end{array}$ & $\begin{array}{lr}\text { independent } & \text { samples t- } \\
\text { tests, } & \text { partial } \\
\text { correlations, } & \text { separate } \\
\text { stepwise } & \text { regression } \\
\text { analyses } & \end{array}$ & $\begin{array}{l}70 \text { children } 33 \text { English } \\
\text { monolinguals and } 37 \\
\text { Spanish-English bilinguals }\end{array}$ \\
\hline
\end{tabular}




\begin{tabular}{|c|c|c|c|c|}
\hline Ip et al. (2016) & experimental & $\begin{array}{l}\text { single-word reading tests } \\
\text { in English (Word ID } \\
\text { subtest, Woodcock } \\
\text { Reading Mastery Tests- } \\
\text { Revised [WRMT-R] }\end{array}$ & conjunction analysis & $\begin{array}{l}22 \text { bilingual Chinese-English } \\
\text { and monolingual English } \\
\text { children }\end{array}$ \\
\hline $\begin{array}{l}\text { Patricia et al. } \\
(2016)\end{array}$ & descriptive & questionnaire & $\begin{array}{l}\text { Mann-Whitney } \\
\text { and two-tailed t-test }\end{array}$ & $\begin{array}{l}31 \text { adults, } 16 \text { Spanish- } \\
\text { English bilinguals and } 15 \\
\text { English monolinguals }\end{array}$ \\
\hline Şen, (2016) & survey & document survey & content analysis & Bilingual Turkish children \\
\hline $\begin{array}{l}\text { Kovelman et al. } \\
2015\end{array}$ & $\begin{array}{l}\text { experimental } \\
\text { (phonics } \\
\text { approach) }\end{array}$ & $\begin{array}{l}\text { two 30-min videotaped } \\
\text { testing sessions in each of } \\
\text { their languages }\end{array}$ & MANOVA & $\begin{array}{l}56 \text { Spanish-English bilingual } \\
\text { children }\end{array}$ \\
\hline $\begin{array}{l}\text { Asadollahpour } \\
\text { et al. (2015) }\end{array}$ & descriptive & 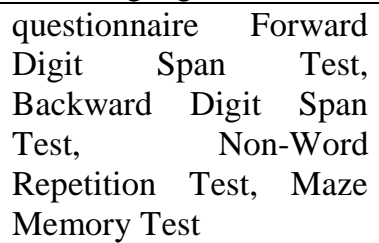 & $\begin{array}{l}\text { factor analysis } \\
\text { ANOVA }\end{array}$ & $\begin{array}{l}70 \text { monolinguals and } 70 \\
\text { bilinguals }\end{array}$ \\
\hline $\begin{array}{lll}\text { Filippi } & \text { et } & \text { al. } \\
(2015) & & \end{array}$ & descriptive & $\begin{array}{l}\text { The British Picture } \\
\text { Vocabulary Scale; } \\
\text { BPVS-II, Digit Span } \\
\text { forward and backward } \\
\text { and Raven's Coloured } \\
\text { Progressive Matrices }\end{array}$ & $\begin{array}{l}\text { Mean raw scores and } \\
\text { standard deviations the } \\
\text { ANOVA, t-tests, } \\
\text { regression analyses }\end{array}$ & $\begin{array}{l}20 \text { monolingual English and } \\
20 \text { bilingual children }\end{array}$ \\
\hline $\begin{array}{l}\text { Zinszer et al. } \\
(2015)\end{array}$ & $\begin{array}{l}\text { experimental } \\
\text { and imaging } \\
\text { methods }\end{array}$ & $\begin{array}{l}\text { scale and } \\
\text { questionnaire }\end{array}$ & mean rating & $\begin{array}{l}24 \text { native Mandarin Chinese } \\
\text { speakers and } 24 \text { speakers } \\
\text { English as a second language }\end{array}$ \\
\hline $\begin{array}{lll}\text { Pons } & \text { et } & \text { al. } \\
(2015) & & \\
\end{array}$ & descriptive & questionnaire & $\begin{array}{l}\text { analysis of variance } \\
\text { (ANOVA) }\end{array}$ & $\begin{array}{l}60 \text { monolingual and } \\
\text { bilingual infants }\end{array}$ \\
\hline $\begin{array}{l}\text { Ratiu et al. } \\
(2015)\end{array}$ & experimental & $\begin{array}{l}\text { simple- complex WM } \\
\text { span tasks, digit-span } \\
\text { task, standard operation } \\
\text { span tasks, a non-verbal } \\
\text { symmetry span task }\end{array}$ & multivariate analysis & $\begin{array}{l}52 \text { bilingual and } 53 \\
\text { monolingual speakers }\end{array}$ \\
\hline $\begin{array}{l}\text { Jalali } \\
\text { Moghadam, et } \\
\text { al. (2015) }\end{array}$ & descriptive & three EF tasks & $\begin{array}{l}\text { analyses of variance } \\
\text { (ANOVAs) }\end{array}$ & $\begin{array}{l}190 \text { children (41 bilinguals, } \\
45 \text { monolinguals, } 45 \\
\text { bilinguals and } 59 \\
\text { monolinguals without RD) }\end{array}$ \\
\hline Sheng (2014) & $\begin{array}{l}\text { longitudinal } \\
\text { study }\end{array}$ & $\begin{array}{l}\text { picture identification } \\
\text { task and picture naming } \\
\text { task }\end{array}$ & mean (sd), percent & $\begin{array}{l}27 \quad \text { Mandarin-English } \\
\text { bilingual children }\end{array}$ \\
\hline $\begin{array}{l}\text { Leikin et al. } \\
(2014)\end{array}$ & $\begin{array}{l}\text { mixed- } \\
\text { method }\end{array}$ & $\begin{array}{l}\text { the figural form a from } \\
\text { the torrance tests, the } \\
\text { pictorial multiple } \\
\text { solution tasks }\end{array}$ & $\begin{array}{l}\text { means and standard } \\
\text { deviations }\end{array}$ & $\begin{array}{l}15 \text { Russian/Hebrew balanced } \\
\text { bilinguals and } 15 \text { native } \\
\text { Hebrew-speaking } \\
\text { monolinguals. }\end{array}$ \\
\hline $\begin{array}{l}\text { Blom et al. } \\
(2014)\end{array}$ & $\begin{array}{l}\text { mixed- } \\
\text { method }\end{array}$ & $\begin{array}{l}\text { interviews } \text { (document), } \\
\text { the toets tweetaligheid, } \\
\text { automated working } \\
\text { memory assessment }\end{array}$ & $\begin{array}{l}\text { mean scores (and } \\
\text { standard deviations), } \\
\text { MANCOVAs }\end{array}$ & $\begin{array}{l}68 \text { bilingual Turkish-Dutch } \\
\text { children }\end{array}$ \\
\hline $\begin{array}{l}\text { Kaushanskaya } \\
\text { et al. (2014) }\end{array}$ & $\begin{array}{l}\text { mixed- } \\
\text { method }\end{array}$ & $\begin{array}{l}\text { pre-switch, post-switch, } \\
\text { and mixed conditions on } \\
\text { the DCCS task }\end{array}$ & $\begin{array}{l}\text { means and standard } \\
\text { deviations, ANOVAs }\end{array}$ & $\begin{array}{l}38 \text { children enrolled in } \\
\text { Kindergarten }\end{array}$ \\
\hline $\begin{array}{l}\text { Nguyen et al. } \\
(2014)\end{array}$ & descriptive & $\begin{array}{lr}\text { verbal } & \text { ability } \\
\text { tests, } & \text { parental } \\
\text { questionnaire } & \\
\end{array}$ & - & $\begin{array}{l}24 \text { English monolinguals and } \\
24 \text { French monolinguals }\end{array}$ \\
\hline $\begin{array}{l}\text { Aguilar- } \\
\text { Mediavilla et al. } \\
(2014)\end{array}$ & descriptive & $\begin{array}{l}\text { letter identification } \\
\text { (decoding), and in the } \\
\text { semantic } \\
\text { (comprehension) }\end{array}$ & regression analyses & $\begin{array}{l}17 \text { bilingual Spanish-Catalan } \\
\text { children }\end{array}$ \\
\hline
\end{tabular}




\begin{tabular}{|c|c|c|c|c|}
\hline \multirow[t]{2}{*}{ Soliman (2014) } & \multirow{2}{*}{$\begin{array}{l}\text { mixed- } \\
\text { method }\end{array}$} & \multirow[t]{2}{*}{ WM tests } & the multi-group & \multirow{2}{*}{$\begin{array}{l}309 \text { monolinguals and } 306 \\
\text { bilinguals }\end{array}$} \\
\hline & & & $\begin{array}{l}\text { confirmatory factor } \\
\text { analysis }\end{array}$ & \\
\hline $\begin{array}{l}\text { Macnamara et } \\
\text { al. (2014) }\end{array}$ & $\begin{array}{l}\text { demographic } \\
\text { information }\end{array}$ & cognitive constructs & means & $\begin{array}{lr}21 & \text { ASL-English } \\
\text { simultaneous } & \text { interpreting } \\
\text { students } & \end{array}$ \\
\hline $\begin{array}{l}\text { Timmer et al. } \\
(2014)\end{array}$ & case study & $\begin{array}{l}\text { L2 words, } \\
\text { electroencephalography } \\
\text { (EEG) }\end{array}$ & $\begin{array}{l}\text { phonological but not } \\
\text { orthographic overlap } \\
\text { facilitated RTs }\end{array}$ & 25 Dutch-English bilinguals \\
\hline $\begin{array}{l}\text { Paap et al. } \\
(2014)\end{array}$ & descriptive & point scale & $\begin{array}{l}\text { regression analyses, } \\
\text { t-tests }\end{array}$ & 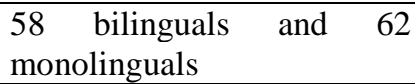 \\
\hline $\begin{array}{l}\text { Jasińska et al. } \\
\text { (2013) }\end{array}$ & $\begin{array}{l}\text { an event- } \\
\text { related } \\
\text { method }\end{array}$ & $\begin{array}{l}\text { previously validated and } \\
\text { published the } \\
\text { questionnaire }\end{array}$ & $\begin{array}{l}\text { statistical parametric } \\
\text { mapping and multilevel } \\
\text { modeling of changes in } \\
\text { HbO concentrations } \\
\text { (behavioral analysis) }\end{array}$ & $\begin{array}{l}20 \text { bilingual and } 20 \text { English, } \\
\text { monolingual children } 10 \\
\text { bilingual adults }\end{array}$ \\
\hline $\begin{array}{l}\text { Smithson et al. } \\
(2013)\end{array}$ & experimental & - & 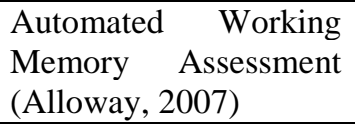 & monolinguals and bilinguals \\
\hline $\begin{array}{l}\text { Sasisekaran et } \\
\text { al. (2013) }\end{array}$ & experimental & standardized tests & $\begin{array}{l}\text { a logistic mixed model } \\
\text { analysis, linear } \\
\text { regression analysis }\end{array}$ & $\begin{array}{l}20 \text { adults who spoke English } \\
\text { monolinguals and } \\
\text { participants bilinguals }\end{array}$ \\
\hline $\begin{array}{l}\text { Morales et al. } \\
(2013)\end{array}$ & descriptive & $\begin{array}{l}\text { the Peabody Picture } \\
\text { Vocabulary Test (PPVT- } \\
\text { III, Kaufman Brief } \\
\text { Intelligence Test }\end{array}$ & $\begin{array}{l}\text { two-way analyses of } \\
\text { variance (ANOVA), } \\
\text { mean scores and } \\
\text { standard deviation }\end{array}$ & $\begin{array}{l}56 \text { children bilingual } \\
125 \text { children monolingual }\end{array}$ \\
\hline Sung, 2013 & descriptive & Questionnaire & $\begin{array}{l}\text { SPSS statistical } \\
\text { MANOVA }\end{array}$ & 130 bilingual \\
\hline $\begin{array}{l}\text { Klein et al. } \\
(2013)\end{array}$ & $\begin{array}{r}\text { experimental } \\
\text { phonics } \\
\text { approach } \\
\end{array}$ & MRI data sets & $\begin{array}{l}\text { the general linear } \\
\text { model, } \\
\text { chi-squared test }\end{array}$ & $\begin{array}{l}22 \text { monolinguals and } 66 \\
\text { bilinguals }\end{array}$ \\
\hline Luk et al. (2013) & descriptive & questionnaire & factor analysis & 110 bilingual young adults \\
\hline $\begin{array}{l}\text { Abutalebi et al. } \\
(2013)\end{array}$ & experimental & $\begin{array}{l}\text { Magnetic Resonance (er- } \\
\text { fMRI) }\end{array}$ & $\begin{array}{l}\text { Matlab-based NIRS- } \\
\text { SPM }\end{array}$ & $\begin{array}{l}14 \text { multilingual and } 14 \\
\text { monolinguals }\end{array}$ \\
\hline $\begin{array}{l}\text { Filippi et al. } \\
(2012)\end{array}$ & descriptive & $\begin{array}{l}\text { the questionnaire, } \\
\text { standardized test, the } \\
\text { bilingual verbal ability } \\
\text { tests }\end{array}$ & $\begin{array}{l}\text { initial analysis of mean } \\
\text { accuracy and individual } \\
\text { median reaction }\end{array}$ & $\begin{array}{l}60 \text { adults Italian-English } \\
\text { bilinguals }\end{array}$ \\
\hline $\begin{array}{l}\text { Bialystok et al. } \\
(2012)\end{array}$ & descriptive & $\begin{array}{l}\text { peabody picture } \\
\text { vocabulary test }\end{array}$ & one-way ANOVA & $\begin{array}{l}797 \text { monolinguals and } 808 \\
\text { bilinguals }\end{array}$ \\
\hline $\begin{array}{l}\text { Engel de Abreu } \\
\text { et al. (2012) }\end{array}$ & descriptive & $\begin{array}{l}\text { visuospatial tests, } \\
\text { abstract reasoning, } \\
\text { selective attention, and } \\
\text { interference suppression }\end{array}$ & $\begin{array}{l}\text { principal component } \\
\text { analysis }\end{array}$ & $\begin{array}{lr}40 & \text { Portuguese- } \\
\text { Luxembourgish } & \text { bilingual } \\
\text { children and } 40 \text { monolingual } \\
\text { children }\end{array}$ \\
\hline $\begin{array}{l}\text { Engel de Abreu } \\
(2011)\end{array}$ & descriptive & $\begin{array}{l}\text { the questionnaire, } \\
\text { expressive one-word } \\
\text { picture vocabulary test }\end{array}$ & $\begin{array}{l}\text { Skew and Kurtosis, } \\
\text { descriptive statistics, } \\
\text { mixed analysis of } \\
\text { variance (ANOVAs) }\end{array}$ & $\begin{array}{l}44 \text { bilingual monolingual } \\
\text { children }\end{array}$ \\
\hline $\begin{array}{l}\text { Kaushanskaya } \\
\text { et al. (2011) }\end{array}$ & experimental & $\begin{array}{l}\text { the peabody picture } \\
\text { vocabulary test-iii }\end{array}$ & $\begin{array}{l}\text { t-tests, Pearson } \\
\text { correlation analyses }\end{array}$ & $\begin{array}{l}24 \text { English-Spanish } \\
\text { bilinguals and } 30 \text { English- } \\
\text { speaking monolinguals }\end{array}$ \\
\hline $\begin{array}{l}\text { Adi-Japha et al. } \\
(2010)\end{array}$ & experimental & $\begin{array}{l}\text { peabody picture } \\
\text { vocabulary test-iii, the } \\
\text { visual reception test, the } \\
\text { drawing complexity scale }\end{array}$ & analysis of variance & $\begin{array}{l}15 \text { monolingual and } 15 \\
\text { bilingual children }\end{array}$ \\
\hline $\begin{array}{l}\text { Farhadian et al. } \\
(2010)\end{array}$ & $\begin{array}{l}\text { stratified } \\
\text { simple } \\
\text { random } \\
\text { sampling } \\
\text { method } \\
\end{array}$ & $\begin{array}{l}\text { theory of mind tasks, } \\
\text { red/blue box crayon box } \\
\text { /sticker or change of } \\
\text { content, McCarthy scales }\end{array}$ & $\begin{array}{l}\text { mean and standard } \\
\text { deviation }\end{array}$ & $\begin{array}{l}163 \text { bilingual } \\
\text { monolingual }\end{array}$ \\
\hline
\end{tabular}




\begin{tabular}{|c|c|c|c|c|}
\hline $\begin{array}{l}\text { Proctor et al. } \\
(2010)\end{array}$ & $\begin{array}{l}\text { structural } \\
\text { equation } \\
\text { modeling }\end{array}$ & reading data & $\begin{array}{l}\text { one-way ANOVAs } \\
\text { with Tukey's post-hoc } \\
\text { testing }\end{array}$ & $\begin{array}{l}\text { 91 Spanish-English bilingual } \\
\text { students }\end{array}$ \\
\hline Wu et al. (2010) & experimental & $\begin{array}{l}\text { the semantic-relatedness } \\
\text { tasks }\end{array}$ & ANOVA & $\begin{array}{l}30 \text { native English speakers, } \\
30 \text { native Chinese speakers, } \\
\text { and } 30 \text { Chinese-English } \\
\text { bilinguals }\end{array}$ \\
\hline $\begin{array}{l}\text { Bialystok et al. } \\
(2008)\end{array}$ & experimental & $\begin{array}{l}\text { tasks assessing working } \\
\text { memory, lexical retrieval }\end{array}$ & ANOVA & $\begin{array}{l}24 \text { young monolinguals, } 24 \\
\text { young bilinguals, } 24 \text { older } \\
\text { monolinguals, and } 24 \text { older } \\
\text { bilinguals }\end{array}$ \\
\hline $\begin{array}{l}\text { Carlson et al. } \\
(2008)\end{array}$ & experimental & $\begin{array}{l}\text { the questionnaire, verbal } \\
\text { ability control measure }\end{array}$ & ANOVA & $\begin{array}{ll}33 \text { Bilingual } & \text { group, } 17 \\
\text { English } & \text { monolingual } \\
\text { children } & \\
\end{array}$ \\
\hline $\begin{array}{l}\text { Colzato et al. } \\
(2008)\end{array}$ & experimental & Questionnaire & $\begin{array}{l}\text { analysis of variance } \\
\text { (ANOVA) }\end{array}$ & $\begin{array}{l}32 \text { healthy young adults two } \\
\text { language groups: } \\
\text { monolingual and bilingual }\end{array}$ \\
\hline $\begin{array}{lll}\text { Oller } & \text { et } & \text { al. } \\
(2007) & & \end{array}$ & experimental & Questionnaire & $\begin{array}{l}\text { the reanalyzed } \\
\text { (the vertical) }\end{array}$ & $\begin{array}{l}952 \text { children (704 bilinguals, } \\
248 \text { monolinguals) }\end{array}$ \\
\hline Kemp, (2007) & experimental & Likert scale & $\begin{array}{l}\text { Correlation (Spearman, } \\
\text { Mann-Whitney U-test) }\end{array}$ & $\begin{array}{l}144 \text { participants who knew } \\
\text { between } 2 \text { and } 12 \text { languages }\end{array}$ \\
\hline $\begin{array}{l}\text { Golestani et al. } \\
(2006)\end{array}$ & experimental & $\begin{array}{l}\text { structure } \\
\text { (TOEFL) }\end{array}$ & $\begin{array}{ll}\begin{array}{l}\text { generating } \\
\text { model, }\end{array} & \begin{array}{l}\text { a linear } \\
\text { three-way } \\
\text { ANOVA }\end{array} \\
\end{array}$ & $\begin{array}{l}12 \text { English bilingual native } \\
\text { French speakers }\end{array}$ \\
\hline $\begin{array}{l}\text { Demie et al. } \\
(2006)\end{array}$ & $\begin{array}{l}\text { experimental } \\
\text { case study } \\
\text { local } \\
\text { authority }\end{array}$ & scales & $\begin{array}{l}\text { statistical regression } \\
\text { analysis }\end{array}$ & $\begin{array}{l}2279 \text { pupils in the } 10 \\
\text { secondary schools in the } \\
\text { Local Authority }\end{array}$ \\
\hline $\begin{array}{l}\text { Ransdell et al. } \\
(2006)\end{array}$ & descriptive & $\begin{array}{l}\text { reading comprehension } \\
\text { subtest }\end{array}$ & descriptive statistics & $\begin{array}{l}58 \text { participants were } \\
\text { primarily monolingual and } \\
48 \text { participants were } \\
\text { bilingual students }\end{array}$ \\
\hline $\begin{array}{l}\text { Meschyan et al. } \\
(2005)\end{array}$ & descriptive & questionnaire & $\begin{array}{l}\text { statistical parametric } \\
\text { mapping }\end{array}$ & $\begin{array}{l}20 \text { Spanish-English bilingual } \\
\text { college students }\end{array}$ \\
\hline $\begin{array}{l}\text { Yang } \\
(2005)\end{array}$ et al. & survey & $\begin{array}{l}\text { three WM-span tests and } \\
\text { set size ( } 3 \text { vs. } 6)\end{array}$ & correlation & $\begin{array}{l}17 \text { balanced English-Korean } \\
\text { bilinguals and } 10 \text { English } \\
\text { monolinguals }\end{array}$ \\
\hline $\begin{array}{l}\text { Berguno et al. } \\
(2004)\end{array}$ & experimental & $\begin{array}{l}\text { scales and the deceptive } \\
\text { objects }\end{array}$ & $\begin{array}{ll}\begin{array}{l}\text { separate } \\
\text { analyses }\end{array} & \text { chi-square } \\
\end{array}$ & $\begin{array}{l}140 \text { single language users } \\
\text { and } 57 \text { dual language users }\end{array}$ \\
\hline $\begin{array}{l}\text { Keshavarz et al. } \\
(2004)\end{array}$ & descriptive & $\begin{array}{l}\text { controlled productive } \\
\text { ability test }\end{array}$ & $\begin{array}{l}\text { multiple t-test, } \\
\text { descriptive statistics }\end{array}$ & $\begin{array}{l}30 \text { Turkish-Persian } \\
\text { bilinguals, } 30 \text { Armenian- } \\
\text { Persian bilinguals, and } 30 \\
\text { Persian monolinguals }\end{array}$ \\
\hline $\begin{array}{l}\text { Bialystok et al. } \\
(2003)\end{array}$ & experimental & $\begin{array}{l}\text { the forward digit span } \\
\text { task from the Wechsler } \\
\text { intelligence scale }\end{array}$ & $\begin{array}{l}\text { two-way analysis of } \\
\text { variance (ANOVA) }\end{array}$ & $\begin{array}{l}72 \text { children in the study, } 36 \\
\text { English-French bilinguals }\end{array}$ \\
\hline $\begin{array}{l}\text { De Bleser et al. } \\
(2003)\end{array}$ & $\begin{array}{l}\text { positron } \\
\text { emission } \\
\text { tomography } \\
\text { experiment }\end{array}$ & $\begin{array}{l}\text { internally naming } \\
\text { pictures of objects and } \\
\text { fMRI }\end{array}$ & - & $\begin{array}{l}11 \text { Belgian subjects who } \\
\text { were native speakers of } \\
\text { Flemish/Dutch and had good } \\
\text { proficiency in French. }\end{array}$ \\
\hline $\begin{array}{l}\text { Abu-Rabia et al. } \\
(2002)\end{array}$ & descriptive & $\begin{array}{l}\text { language and memory } \\
\text { tasks }\end{array}$ & statistical analysis & $\begin{array}{l}56 \text { bilingual Arab-Canadian } \\
\text { children }\end{array}$ \\
\hline Petitto (2001) & experimental & $\begin{array}{l}\text { videotaped } \text { MacArthur } \\
\text { CDI data }\end{array}$ & $\begin{array}{l}\text { transcription } \\
\text { coding }\end{array}$ & $\begin{array}{l}3 \text { children Signes } \\
\text { Quebecoise and French, and } \\
3 \text { children acquiring French } \\
\text { and English }\end{array}$ \\
\hline $\begin{array}{l}\text { D’Angiulli } \\
(2001)\end{array}$ & descriptive & $\begin{array}{l}\text { phonological, reading, } \\
\text { spelling, syntactic, and } \\
\text { working memory tasks }\end{array}$ & analysis of variance & $\begin{array}{l}81 \text { Canadian children who } \\
\text { spoke both English and } \\
\text { Italian }\end{array}$ \\
\hline
\end{tabular}




\section{İki dillilik odaklı çalışmalar üzerine bir inceleme}

\section{$\ddot{\mathbf{O} z}$}

Bu çalışmanın amacı iki dillilikle ile ilgili araştırmaların odak noktası, kapsamı, araştırma modeli, veri toplama arac1, veri analiz yöntemi ve örneklem büyüklüğünün nasıl olduğunu belirlemektir. Genel tarama modeline göre toplanan dokümanlar, betimsel analiz tekniğine göre çözümlenmiştir. Araştırma sorularına göre veriler, iki aşamada çözümlenmiştir. Birinci aşamada odak noktası ve kapsamı belirlemek için örnek çalışmaların amaçları, betimsel analize göre incelenmiştir. Araştırmaların odak noktası ve kapsamını belirlemek için araştırmaların amaç bölümünde verilen bağımlı ve bağımsız değişkenler kullanılmıştır. İkinci aşamada ise örnek çalışmaların araştırma modeli, veri toplama araçları, veri çözümleme yöntemleri ve katılımcılarla ilgili özellikler incelenmiştir. Bu kapsamda örnek araştırmalar dört kategoride incelenmiştir. Bu kategorilerin birbiri ile olan ilişkilerine bakılmıştır. Çözümleme sonucundaki bulgular iki bölümde ele alınmıştır. Birinci bölümde araştırmaların bağımsız değişkeni olan iki dillik, iki dillilik/tek dillilik ve tek dillilik ile ilgili odak noktaları saptanmıştır. Bu üç bağımsız değişkenden (odak noktası) hareketle bağımlı değişkenler olan dil becerileri, beyin, öğrenme-öğretme, işleyen bellek, bilişsel beceriler belirlenmiştir. İkinci bölümde ise örnek araştırmalardaki araştırma modelleri, veri toplama araçları, veri analiz yöntemleri ve katılımcı sayısı incelenmiştir. Bu bölümdeki bulgulara göre araştırmalarda betimleyici ve deneysel modellerin sıklıkla kullanıldığı, veri toplama aracı olarak ise çoğunlukla testlere başvurulduğu ve verilerin çoğunlukla parametrik testlerle analiz edildiği belirlenmiştir. Bunlara ek olarak araştırmaların genellikle 21-40 katılımcının olduğu örneklem grubuyla yapıldığı belirlenmiştir. Ulaşılan bulguların sonuçları, tartışma bölümünde iki dilli eğitimin ihtiyaçları ve araştırma yöntemlerine bağlı olarak değerlendirilmiştir.

Anahtar sözcükler: iki dillilik; amaç; kapsam; eğitim.

\section{AUTHOR BIODATA}

Author started her high school education at Kilis Nedim Ökmen Anatolian Teacher's High School and for her license degree she graduated from Department of Turkish Language and Literature Teaching, Van Yüzüncü Y1l University. In 2008, she started working as a research assistant at the Department of Turkish Language Teaching, Faculty of Education, Muş Alparslan University. For master she graduated from Institute of Educational Sciences, Department of Turkish Language Teaching, İnönü University in 2011. For PhD she graduated from Institute of Educational Sciences, Department of Turkish Language Teaching, Marmara University, in 2017. In 2018 she started to work as Dr. Instructor at Faculty of Education, Department of Turkish Language Teaching, Muş Alparslan University and she still continues to work there. 